\title{
Differentiation and Growth
}

National Cancer Institute

\section{Source}

National Cancer Institute. Differentiation and Growth. NCI Thesaurus. Code C18745.

A funding category for studies concerned with cell growth or cell differentiation. 